\title{
Síndrome de Morel-Lavallée glúteo
}

\author{
Gluteal Morel-Lavallée syndrome
}

Ester Ferrer Inaebnit ${ }^{1}$, Marina Jiménez Segovia ${ }^{1}$ y Alcides Velásquez ${ }^{1}$

Varón de 41 años, acudió a urgencias por dolor y tumoración glútea, junto sensación distérmica, tras caída hace 3 semanas. A la exploración se objetiva extenso empastamiento y flogosis del glúteo, doloroso a la palpación. En la analítica presenta leucocitosis $12.000 \mathrm{u} / \mathrm{L}$, neutrofília $75 \%$ y PCR $22,19 \mathrm{mg} / \mathrm{dl}$.

Se solicitó una ecografía (Figura 1), y dada las características de la lesión se amplia el estudio a TC que informó de colección líquida multiseptada $(14 \times 4,6 \times 14 \mathrm{~cm})$ entre la grasa subcutánea y plano facial profundo, sugestivo de Morel-Lavallée (Figura 2).

Se realizó drenaje quirúrgico, con incisión en zona de pliegue glúteo izquierdo (Figura 3), posterior disección roma del tejido subcutáneo hasta

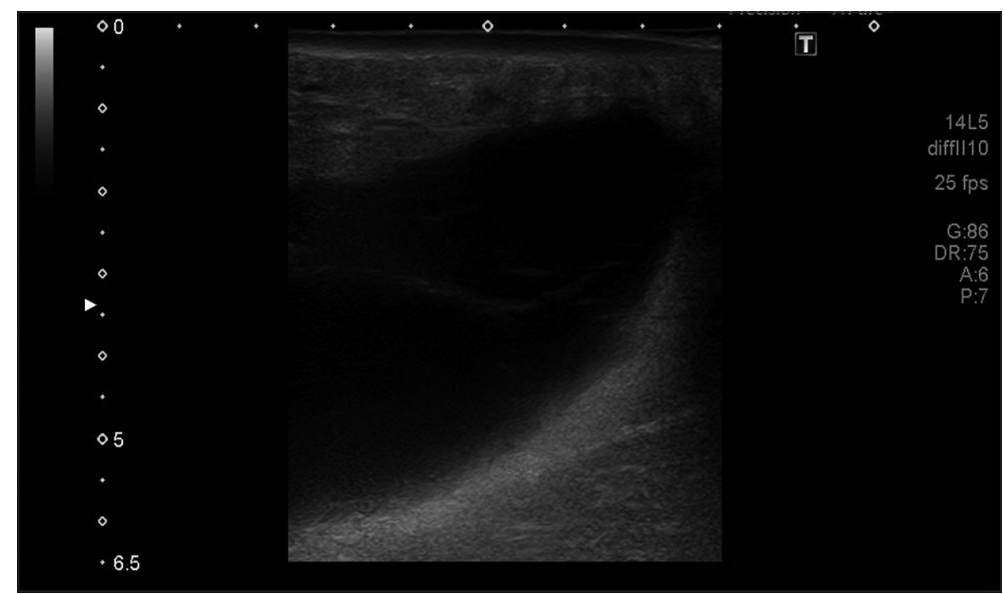

Figura 1. Ecografía glútea: Colección líquida encapsulada de morfología fusiforme situada a nivel subcutáneo en la región glútea izquierda, entre la grasa subcutánea y el plano facial profundo. Es una colección anecoica multiseptada y con algunas áreas ecogénicas de pequeño tamaño.
${ }^{1}$ Hospital Universitario Son Espases Palma de Mallorca. España.

Recibido 2021-07-07 aceptado 2021-07-27

Correspondencia a: Dra. Ester Ferrer Inaebnit esterinaebnit@gmail.com

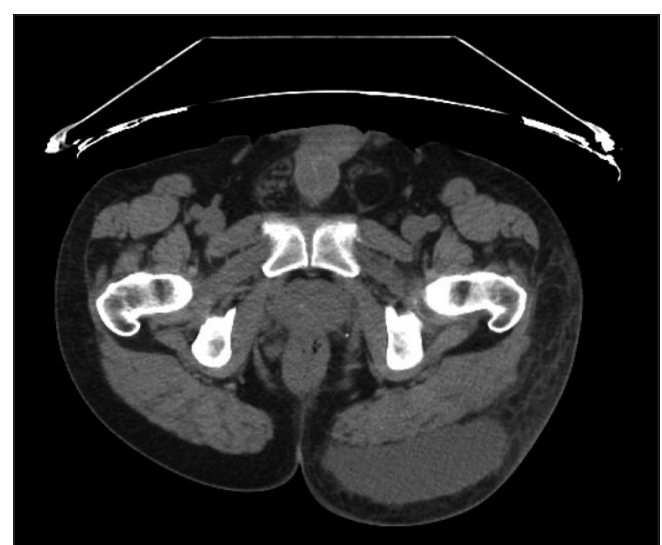

Figura 2. TC pélvica: Colección líquida de aproximadamente 14 x 4,6 $\times 14 \mathrm{~cm}$ (T-A-L). Estriación de la grasa subcutánea que rodea la colección y engrosamiento de la piel. Pequeño engrosamiento a nivel de la banda iliotibial izquierda sin colección líquida asociada.

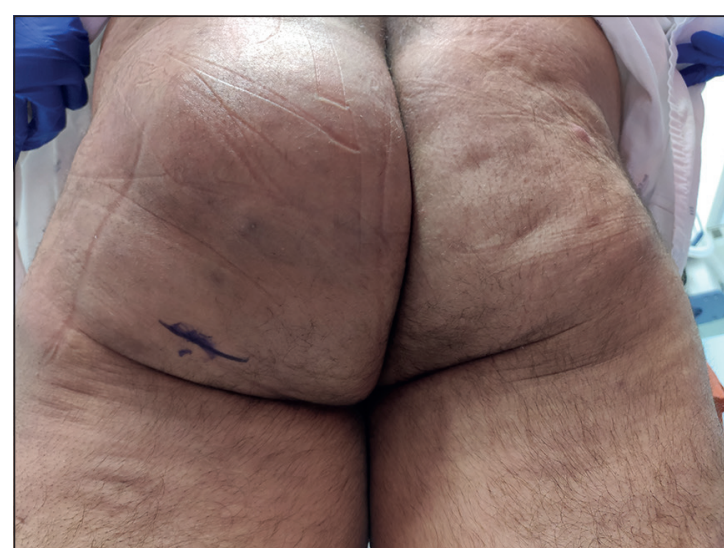

Figura 3. Marcaje de incisión de unos $3 \mathrm{~cm}$ en área declive con el paciente en bipedestación, en zona de pliegue glúteo izquierdo. 
alcanzar la cavidad, obteniendo abundante salida de trasudado serohemático. Se realizó drenaje con maniobra con rodillo compresiva, dejando drenaje Penrose. Alta al segundo día posoperatorio tras la retirada del Penrose.

Reingresó a los 5 días por recidiva del derrame glúteo, realizándose nuevo drenaje, dejando un
Blake en cavidad glútea. Dado de alta con el drenaje, reacudió a los 2 días por pérdida del Blake y reproducción de la tumoración. Se realizó nuevo drenaje y recolocación de drenaje.

Posterior seguimiento en consultas externas presentando correcta evolución, permitiendo la retirada del drenaje, sin nueva recidiva. 